\title{
EPIDEMIOLOGICAL STUDY OF CANINE TRYPANOSOMOSIS IN AN URBAN AREA OF IVORY COAST
}

\author{
KECK N.*, HERDER S.*, KABA D.**, SOLANO P.***, GOMEZ J.***, CUNY G.* \& DAVOUST B.****
}

\section{Summary:}

Following confirmed cases of trypanosomosis in military working dogs, a cross-sectional study was undertaken to evaluate the source of infection and determine the prevalence of canine infection with Trypanosoma congolense in the urban focus of Abidjan, Ivory Coast. Blood from 123 dogs were collected and subjected to PCR using specific primers for Trypanosoma congolense "forest type". In addition, an entomological study was conducted in an urban area near the forest surronding the military camp. The observed prevalence was $30.1 \%$ and PCR positivity to Trypanosoma congolense was not significantly associated with sex or age of animals. This study demonstrates the high contamination rate of dogs in enzootic zones, the potential risk of introduction of the disease in free animal populations and the ability of Glossina palpalis to adapt to urban areas and to transmit trypanosomosis in such areas. The factors leading to a possible emergence of canine trypanosomiasis in enzootic zones need further investigations.

KEY WORDS : Trypanosoma congolense "forest type", dog, Glossina palpalis palpalis, Ivory Coast.
Résumé : ÉTUDE ÉPIDÉMIOLOGIQUe DE LA TRYPANOSOMOSE CANINE DANS UN FOYER URBAIN DE CÔTE D'IVOIRE

Après la confirmation de cas de trypanosomose chez des chiens militaires, une étude transversale a été entreprise afin de déterminer la source de l'infection et la prévalence de Trypanosoma congolense chez le chien dans le foyer urbain d'Abidjan, Côte d'lvoire. Le sang de 123 chiens a été prélevé et analysé par PCR à l'aide d'amorces spécifiques de Trypanosoma congolense "type forêt". De plus, une enquête entomologique a été conduite en zone urbaine et à proximité de la forêt entourant le camp militaire. La prévalence observée était de 30,1\%; le fait d'être positif à la PCR à T. congolense n'était pas associé significativement au sexe ou à l'âge de l'animal. Cette étude a montré le fort taux de contamination des chiens dans cette zone enzootique, le risque potentiel d'introduction de la maladie dans une population animale naïve et la capacité de Glossina palpalis de s'adapter et de transmettre la trypanosomose dans un environnement urbain/péri-urbain. Des études complémentaires permettant de mieux cerner les facteurs pouvant conduire à une émergence de la trypanosomose canine en zone enzootique sont nécessaires.

MOTS CLÉS : Trypanosoma congolense "type forêt", chien, Glossina palpalis palpalis, Côte d'lvoire.

\section{INTRODUCTION}

A frican trypanosomiasis due to Trypanosoma congolense is a major threat to livestock production in sub-Saharan Africa. It is transmitted cyclically by tsetse flies (Diptera: Glossinidae). Although the disease mainly concerns cattle, it may also infect a large range of domestic and wild animals. It has been particularly observed in military working dogs in a French squad ( $43^{\text {rd }}$ BIMa) located in Abidjan, Ivory Coast, where several dogs died suddenly between 2000 and

\footnotetext{
* Laboratoire de recherches et de coordination sur les trypanosomoses, Institut de recherche pour le développement / Centre de coopération internationale en recherche agronomique pour le développement, TA A-17/G 34398 Montpellier Cedex 5, France.

** Institut Pierre Richet / Institut de recherche pour le développement (IRD), 04 BP 293, Abidjan 04, Côte d'Ivoire.

**:* Veterinary practitioner, 06 BP 178, Abidjan 06, Côte d'Ivoire.

**:**: Direction régionale du service de santé des Armées de Toulon, BP 20549, 83041 Toulon Cedex 9, France.

Correspondence: Stephane Herder.

Tel.: +33 (0)4 675942.47 - Fax: +33 (0)4 67593894

E-mail: herder@mpl.ird.fr
}

2001. At this time, infection by T. congolense "forest type" was incriminated (Davoust et al., 2006a) and it was decided to administrate an isometamidium preventive treatment to each military dog.

Hence, this disease appeared to be a significant veterinary problem for cynophilic sections in this region, and it was necessary to evaluate its origin and define a vector control strategy. In order to evaluate the risk of infection, the presence of the vector Glossina palpalis palpalis was studied by an entomological survey around this zone. Furthermore, the presence of infected dogs was investigated. The present study reports the results of these investigations and discusses epidemiological patterns and risk factors.

\section{MATERIAL AND METHODS}

Whe climate of the area is characterised by a rainy season during approximately four months and by a dry season covering the remaining months. Temperatures vary between 21 and $33^{\circ} \mathrm{C}$ and 
humidity between 80 and $90 \%$. The data were collected between November and December 2003, during a cross-sectional survey of the dog population of Abidjan (Ivory Coast). Consenting owners provided the age and sex of each animal and the study mainly concerned watch dogs which are more exposed to the disease because of their outdoor way of life. A total of 123 dogs were sampled. The sampling involved more male dogs (65.9\%) than females (34.1\%). Young dogs ( $<3$ years) were more numerous $(54.5 \%)$ than older dogs ( $45.5 \%$ for $3-8$ years dogs and $4.1 \%$ for dogs older than nine years). From each of the 123 animals, blood was sampled on Whatman filter paper $\mathrm{N}^{\circ} 4$ and kept frozen before DNA extraction.

The entomological survey was carried out within the $43^{\text {rd }}$ BIMa by placing 22 Vavoua traps (Laveissière and Grébaut, 1990) during three different periods (April 2003, November 2003 and March to May 2004) in order to capture the seasonal variations in the vector density. Three traps were placed around the kennel, three around the horses, and the others along the perimeter of the BIMa, particularly on the east side near the forest. Flies were collected every day during four consecutive days. Insects were counted, sex was recorded, and they were dissected daily in order to determine their age and detect the presence of trypanosomes. For the dissection, the mouthparts were first removed to prevent contamination from the midgut, and dissecting instruments were cleaned between each organ dissection with sodium hypochlorite followed by rinsing in sterile water. Each organ (mouthparts, salivary glands, midgut) was put into a separate eppendorf tube containing $30 \mu \mathrm{l}$ sterile distilled water.

In the laboratory, blood impregnated Whatman papers were placed in an eppendorf tube containing $1 \mathrm{ml}$ of a Chelex $100^{\circledR} 5 \%(\mathrm{w} / \mathrm{v})$ solution. The tube was then heated at $55^{\circ} \mathrm{C}$ for one hour and 30 minutes at $95^{\circ} \mathrm{C}$. After centrifugation at $15,000 \mathrm{rpm}$ for 10 minutes, the supernatant containing the DNA was diluted $(1 / 10$, $1 / 100)$ and used directly as template for PCR. Dilution was performed to avoid inhibition of the enzyme Taq DNA polymerase due to blood residues. Primers specific for T. congolense "forest type" (Masiga et al.,
1992) were used. Amplifications were performed in a final volume of $50 \mu \mathrm{l}$ containing $2 \mu \mathrm{l}$ of diluted DNA extract (template), $10 \mathrm{mM}$ Tris- $\mathrm{HCl}$ ( $\mathrm{pH}$ 9), $50 \mathrm{mM} \mathrm{KCl}$, $3 \mathrm{mM} \mathrm{MgCl}_{2}, 20$ picomoles of each primer, $200 \mu \mathrm{M}$ of each dNTP and one unit of Taq DNA polymerase (Appligene-Oncor, USA). One denaturing step at $94^{\circ} \mathrm{C}$ for five minutes was followed by 40 amplification cycles. Each cycle was constituted by a denaturation step at $94^{\circ} \mathrm{C}$ for 30 seconds, an annealing step at $55^{\circ} \mathrm{C}$ for 30 seconds and an extension step at $72^{\circ} \mathrm{C}$ for one minute. This was followed by a final extension at $72^{\circ} \mathrm{C}$ for 10 minutes. PCR products were separated on $2 \%$ agarose gel and stained with ethidium bromide $(0.3 \mu \mathrm{g} /$ $\mu 1)$. Polymerase chain reaction on tsetse samples was performed with a simple $1 \%$ Chelex $100^{\circledR} 5 \%$ treatment used to obtain DNA for PCR reactions, as in Solano et al., 1999. The following primers were used: TBR1-2 specific for T. brucei, TCF 1-2 specific for T. congolense forest type, TCS 1-2 specific for T. congolense Savannah and TV1-2. specific for T. vivax.

Odds Ratios (OR) for each risk factor and $\mathrm{Khi}^{2}$ test were calculated with Epi-Info ${ }^{\circledR}$. The level of significance was set at $5 \%$.

\section{RESULTS}

The prevalence obtained in the whole population studied was $30.1 \%$ (25.1-35\%). The 11 dogs sampled inside the BIMa were all negative but had recently arrived from France and received an isometamidium treatment at their arrival. There was no association between positivity and the sex of the animals $\left(\mathrm{OR}=0.67, \mathrm{IC}_{95 \%}=[0.28-1.62]\right)$ nor with their age $(\mathrm{p}=0.311)$.

The results of the entomological survey during the three periods are summarized in table I. Glossina palpalis palpalis was the only captured species. They were present in high densities, mainly in the traps situated on the east side of the BIMa near the forest, but very few around the kennel and the horses ( $<0.2 \mathrm{fly} /$ trap/day). Density was lower in November 2003, probably because of an unexpected spreading of insecticide per-

\begin{tabular}{|c|c|c|c|c|c|c|}
\hline & & $\begin{array}{c}\text { April } \\
2003\end{array}$ & $\begin{array}{c}\text { November } \\
2003\end{array}$ & $\begin{array}{c}\text { March } \\
2004\end{array}$ & $\begin{array}{l}\text { April } \\
2004\end{array}$ & $\begin{array}{l}\text { May } \\
2004\end{array}$ \\
\hline Density & & 5.92 & 1.1 & & 2.95 & \\
\hline Sex-ratio $(F / M)$ & & 1.33 & 1.15 & & 1.32 & \\
\hline Number of tsetse flies & $\begin{array}{l}\text { Captured } \\
\text { Dissected } \\
\text { Infected }\end{array}$ & $\begin{array}{r}427 \\
62 \\
16\end{array}$ & $\begin{array}{l}88 \\
58 \\
12\end{array}$ & 374 & $\begin{array}{r}236 \\
248 \\
52\end{array}$ & 170 \\
\hline Infection rate $(\%)$ & & 25.8 & 20.7 & & 20.96 & \\
\hline
\end{tabular}

Table I. - Results of the different tsetse trapping period: details of sampled flies and infection rates (density is expressed in number of tsetse flies/trap/day). 
formed at the first day of the collection. During 2004, the density progressively decreased from March to May. Trypanosome infection rate in the flies was high in the three periods, ranging between 20.7 and $25.8 \%$. PCR analysis showed that the parasites identified belonged to the species T. congolense "forest type" and T. vivax but not to T. congolense "savannah type" not to T. brucei.

\section{DISCUSSION}

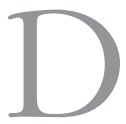
ogs are susceptible to several trypanosomes, mainly T. cruzi causing Chagas disease in America, and also T. congolense, T. brucei and T. evansi in Africa (Abenga et al., 1999; Matete, 2003). Infections with T. brucei appear to be the most pathogenic (Nwosu \& Ikeme, 1992; Matete, 2003). T. congolense infection in dogs may occur in an acute, chronic or subclinical form (Losos \& Ikede, 1972; Sayer et al., 1979; Davoust et al., 2006a). The main symptoms of the acute form are not pathognomonic but hyperthermia, anorexia, anemia, adenomegaly, splenomegaly, haemorrhages, oedematous swelling in different part of the body and neurological signs have been reported (Harrus et al., 1995; Davoust et al., 2006a). Specific antitrypanosome treatments are based on the use of trypanocidal drugs, mainly isometamidium, which can also be used for chemoprophylactic purpose (Davoust et al., 2006b).

In our study, although all dogs sampled were apparently healthy, the prevalence rate of parasitemic animals was high. This may be attributed to the fact that they were infected by $T$. congolense of the Forest type, which has been reported to be poorly virulent and gave low parasitemias in mice and cattle (Bengaly et al., 2002a, b). Hence, the parasitemia may be low and cyclic for indigenous dogs so they tend to be chronic carriers and may serve as a reservoir for infection (Hörchner et al., 1985). In contrast, non-indigenous dogs may show a persistent high parasitemia and die rapidly after infection. Few imported cases of $T$. congolense infection have been reported during the past 20 years (Harrus et al., 1995; Davoust et al.,2006b; Gow et al., 2007). The acute flare up of chronic disease could be due to the stress caused by environmental changes or an underlying disease process.

The prevalence observed in this study may be overestimated since $95 \%$ of the dogs sampled were watch dogs and thus were probably more exposed to the disease than pet dogs. Sex and age do not seem to be risk factors for this disease. PCR is a very sensitive tool for estimation of prevalence of trypanosomiasis (Solano et al., 1999). The major problem is to know whether dogs found positive with this technique will become ill and when they will show the first signs of the disease.
Glossina palpalis palpalis were present in high densities and the rate of infected flies was high during the three periods of sampling. This observation confirms the ability of $G$. palpalis to adapt to big urban centers such as Abidjan where it is also able to transmit trypanosomosis, provided microclimatic conditions and host availability are met. It also strengthens the need to monitor a potential risk of transmission of sleeping sickness, such epidemics having been described in other big towns (Kinshasa, see Ebeja et al., 2003).

\section{CONCLUSION}

T This study demonstrates the high contamination rate of dogs by Trypanosoma congolense in enzootic zones, and the risk they could represent if they were introduced in disease free animal populations. It also emphasizes the need for routine quarantine, including health checks and eventually chemoprophylactic treatments for dogs coming from enzootic zones.

\section{REFERENCES}

Anene B.M., Chukwu C.C. \& Anika S.M. Sensitivity of diaminazene aceturate and isometamidium chloride of trypanosomes isolated from dogs in Nsukka Area, Nigeria. Rev. Elev. Med. Vet. Pays Trop., 1999, 52, 273-277.

Bengaly Z., Sidibe I., Boly H., Sawadogo L. \& Desquesnes M. Comparative pathgenicity of three genetically distinct Trypanosoma congolense types in inbred Balb/c mice. Vet. Parasitol., 2002a, 105, 111-118.

Bengaly Z., Sidibe I., Ganaba R., Desquesnes M., Boly H. \& SAWADOGO L. Comparative pathogenicity of three genetically distinct types of Trypanosoma congolense in cattle: clinical observations and haematological changes. Vet. Parasitol., 2002b, 108, 1-19.

Davoust B., Herder S. \& Watrelot-Virieux D. Deux cas de trypanosomoses canines. Nouv. Prat. Vet., 2006a, 143, 5154 (In French).

Davoust B., Herder S. \& Watrelot-Virieux D. Diagnostic, traitement et prevention des trypansosomoses chez le chien. Nouv. Prat. Vet., 2006b, 141, 49-50 (In French).

Ebeja A.K., Lutumba P., Molisho D., Kegels G., Miaka mia Bilenge C. \& Boelaert M. Sleeping sickness in the region of the town of Kinshasa: a retrospective analysis during the surveillance period 1996-2000. Trop. Med. Int. Hlth., 2003, 8, 949-955.

Gow A.G., Simpson J.W. \& Picozzi K. First report of canine African trypanosomosis in the UK. J. Small Anim. Pract., 2007, 48, 658-661.

Harrus S., Harmelin A., Presenty B. \& Bark H. Trypanosoma congolense infection in two dogs. J. Small Anim. Pract., 1995, 36, 83-86. 
Hörchner F., Zillmann U., Metzner M., SchÖnefeld A. \& MehLITZ D. West African dogs as a model for research on trypanotolerance. Trop. Med. Parasitol., 1985, 36, 257-258.

Laveissière C. \& Grébaut P. The trapping of tsetse flies (Diptera: Glossinidae). Improvement of a model: the Vavoua trap. Trop. Med. Parasitol., 1990, 41, 185-192.

Masiga D.K., Smyth A.J., Hayes P., Bromidge T.J. \& Gibson W.C. Sensitive detection of trypanosomes in tsetse flies by DNA amplification. Int. J. Parasitol., 1992, 22, 909-918.

Matete G.O. Occurence, clinical manifestation and the epidemiological implications of naturally occuring canine trypanosomosis in Western Kenya. Onderstepoort J. Vet. Res., 2003, 70, 317-323.

Nwosu C.O. \& IkEme M.M. Parasitaemia and clinical manifestations in Trypanosoma brucei infected dogs. Rev. Elev. Med. Vet. Pays Trop., 1992, 45, 273-277.

Solano P., Michel J.F., Lefrançois T., De La Roceue S., Sidibé I., Zoungrana A. \& Cuisance D. Polymerase chain reaction as a diagnosis tool for detecting trypanosomes in naturally infected cattle in Burkina Faso. Vet. Parasitol., 1999, 86, 95-103.

Reçu le 30 juin 2009

Accepté le 5 octobre 2009 